\title{
INFLUENCE OF SALT STRESS ON THE GROWTH, ELEMENTS CONTENTS AND ANTIOXIDATIVE ENZYMES ACTIVITIES OF PEA (Pisum sativum L. ) PLANT GROWN IN SAND CULTURE.
}

\author{
Elsokkary, I. H. ; E. Abd El Raouf ; A. Mourad and A. Abdelhady \\ Dept. Of Soil and Water Sci., Fac. Agric., Alex. Univ., egypt.
}

\begin{abstract}
Pot experiment was carried out at Faculty of Agriculture, El Bostan, Alexandria University, in order to evaluate the effect of irrigation with $\mathrm{NaCl}$ solutions on the growth characters, elements contents and antioxidative enzymes activities of pea (Pisum sativum variety Master B) plant grown in sand culture.

Split plot layout, in randomized completely block design, experiment with six replicates was carried out. The concentrations of $\mathrm{NaCl}$ in irrigation water were 00,25 , 50,75 and $100 \mathrm{mM}$ prepared in a base nutrient solution.

Seeds of pea were sown in a plastic pot containing $2 \mathrm{~kg}$ prewashed sand. Two samples of plants ( 3 for each) were collected at 20 and 27 days after sowing (DAS) for determination of the growth characters, the concentrations of $\mathrm{Na}^{+}, \mathrm{K}^{+}, \mathrm{Mg}^{2+}$ and $\mathrm{Ca}^{2+}$ and the activities of antioxidative enzymes: catalase (CAT), pyroxidase (POD) and ascorbate peroxidase (APX) in leaves and root of the plant.

The obtained results showed significant decrease in the fresh and dry weights of leaves and root, plant height and leaf area with increasing $\mathrm{NaCl}$ concentration treatments. In addition, the concentrations of $\mathrm{Na}^{+}, \mathrm{K}^{+}$and $\mathrm{Mg}^{2+}$ were lower in leaves than in root while those of $\mathrm{Ca}^{2+}$ were higher in leaves than in root of both 20 and 27 DAS plants.

The results showed significant reductions in the activity of CAT enzyme in leaves and root of 20 and 27 DAS plants with increasing salinity. The lowest significant CAT activities were found with $100 \mathrm{mM} \mathrm{NaCl}$ treatment which represented values of relative reduction of 20.2 and $10.4 \%$ in leaves and 24.3 and $34.2 \%$ in root, respectively.

There were significant increase in the activity of POD in leaves of 20 DAS plants and no significant change in leaves of 27 DAS plants with increasing salinity. The highest significant level of POD activity in leaves of 20 DAS plants $(132.3 \mu \mathrm{M}$ $\mathrm{H}_{2} \mathrm{O}_{2} \mathrm{~min}^{-1}$. $\mathrm{mg}^{-1}$ protein) was found with $100 \mathrm{mM} \mathrm{NaCl}$ treatment which represented a relative increase of $16.6 \%$. However, for 20 DAS plant, there were no significant variations in $\mathrm{POD}$ activity in plant root due to $\mathrm{NaCl}$ treatments while for $27 \mathrm{DAS}$ plants, there were significant decreases in POD activity with increasing salinity. The lowest significant level of POD activity in root of 27 DAS plants $\left(1778 \mu \mathrm{M} \mathrm{H}_{2} \mathrm{O}_{2}\right.$ min $^{-1} \mathrm{mg}^{-1}$ protein) was found with $100 \mathrm{mM} \mathrm{NaCl}$ treatment which represented a relative reduction in POD activity of $35.3 \%$.

There were significant decreases in the activity of APX enzyme in leaves and root of 20 and 27 DAS plants with increasing salinity. The lowest significant levels were found with $100 \mathrm{mM} \mathrm{NaCl}$ treatment which represented values of relative reduction in APX activity of 33.9 and $41.5 \%$ in leaves and 27.0 and $33.1 \%$ in root of 20 and 27 DAS plants, respectively.
\end{abstract}

Keywords: Antioxidative enzymes, catalase, peroxidase, Ascorbate peroxidase, salt stress, pea plant. 


\section{INTRODUCTION}

Salinity in soil and water of irrigation is one of the major abiotic stress that severely limit crop production. It is mainly due to high $\mathrm{Na}^{+}$concentration which would lead, beside $\mathrm{Na}^{+}$toxicity in plant, to the inhibition of either some nutrients uptake by plant, such as $\mathrm{K}, \mathrm{P}, \mathrm{Fe}$ and $\mathrm{Zn}$, water uptake and the growth of root or both (Tester and Davenport, 2003).

In salt-sensitive plants, the growth of shoot and root is permanently reduced (Munns, 2002 and Elsokkary et al., 2010). The deleterious effects of salinity on plant growth is associated with low osmotic potential, nutritional imbalance, specific effect of ion (salt stress) or a combination of these factors (Marschner, 1990; Munns, 2002 and Tester and Davenport, 2003).

Salt stress may lead also to the formation of reactive oxygen species (ROS) such as superoxide radicals $\left(\mathrm{O}_{2}{ }^{-}\right)$, hydrogen peroxide $\left(\mathrm{H}_{2} \mathrm{O}_{2}\right)$, hydroxyl radical $(\mathrm{OH})$ and single oxygen $\left({ }^{1} \mathrm{O}_{2}\right)$. These cytotoxic ROSs can destroy normal cellular membranes and plant tissues via oxidation damage of lipids, proteins and nucleic acids (Hernandez et al., 2001). In order to decrease the damage of oxidation, plants employ enzymatic mechanisms to scavenge ROS and to prevent and limit its toxicity. In this concern, plants possess a number of antioxidative enzymes such as catalase (CAT), peroxidase (POD) and ascorbate peroxidase (APX) and others which can limit and prevent the toxicity of ROS (Dalton et al., 1993 and Tejera et al., 2004).

There are several reports about increasing the activity of antioxidative enzymes in various plant species under saline conditions (Hernandez et al., 1999; Meneguzzo et al., 1999; Rio Gonzalez et al., 2002; Mittler 2002 and Ahmadi et al., 2009). It has been also reported that a positive relationship exists between the activities of antioxidative enzymes and salt tolerance of plants (Wang and Han, 2009). Mittova et al. (2002) found that higher salt tolerant of wild tomato (Lycopesicon pennelli) as compared to the salt-sensitive cultivated tomato ( $L$. esculentum) was correlated with increased activity of antioxidative enzymes; POD and APX and also with high $\mathrm{Na}^{+}$concentration in leaves of the plant.

Wang and Han (2009), in their study on two alfalfa (Medicago sutiva L.) cultivars: slat tolerant and salt sensitive, found that salt stress led to a significant increase in CAT, POD and APX activities in plant leaves of both cultivars. They also found that the percent increases of antioxidative enzymes activities were considerably more in salt-sensitive cultivar than salttolerant cultivar. They suggested that salt tolerant alfalfa cultivar may mainly employ APX enzyme for detoxification $\mathrm{H}_{2} \mathrm{O}_{2}$ in leaves of plant under salt stress, and that salt-sensitive alfalfa cultivar may mainly employ $P O D$ enzyme for scavenging of $\mathrm{H}_{2} \mathrm{O}_{2}$ in leaves of plant under salt-stress.

The objectives of the present study, therefore, were to evaluate the effect of salt stress on the growth, elements concentrations and the activities of the antioxidative enzymes in leaves and root of pea (Pisum sativum L.) plant grown in sand culture. 


\section{MATERIALS AND METHODS}

\section{Experimental Layout:}

Sand culture pot experiment (Hewitt, 1966) was used to evaluate the effect of irrigation with $\mathrm{NaCl}$ solution on the growth and antioxidative enzymes activity of pea (Pisum sativum L.) plant. In order to achieve these objectives, split plot layout, in randomized completely block design with six replicates, was carried out in the greenhouse of Faculty of Agriculture, El Bostan, Alexandria University, Egypt in Jan. 2006.

Irrigation solution: The irrigation treatments included $\mathrm{NaCl}$ concentrations of $00,25,50,75$ and $100 \mathrm{mM}$ in a base solution of half strength modified Hoagland and Arnon nutrient solution (Hewitt, 1966). The concentrations of $\mathrm{N}-\mathrm{NO}_{3}, \mathrm{~N}-\mathrm{NH}_{4}, \mathrm{P}, \mathrm{K}, \mathrm{Ca}, \mathrm{Mg}$ and $\mathrm{S}$ were $112.65,14.52,31.00,197.20,72.35$, 23.90 and $32.00 \mathrm{mg} \mathrm{I}^{-1}$, respectively and those of $\mathrm{B}, \mathrm{Mn}, \mathrm{Cu}, \mathrm{Zn}, \mathrm{Fe}$ and $\mathrm{Mo}$ were $0.25,0.25,0.01,0.025,0.30$ and $0.025 \mathrm{gl}^{-1}$, respectively.

Plant sowing: Seeds of pea (Pisum sativum L.) variety Master $\mathrm{B}$ were surface sterilized by soaking in a solution of $\mathrm{H}_{2} \mathrm{O}_{2}(10 \%)$ for 10 mins, then washed thoroughly by tap water followed by distilled water (Hewitt, 1966). Ten seeds were sown in a plastic pot of $16 \mathrm{~cm}$ inside diameter and $13 \mathrm{~cm}$ depth containing $2 \mathrm{~kg}$ prewashed sand (Hewitt, 1966). Each pot was irrigated daily by $200 \mathrm{ml}$ distilled water for one week, then the plants in each pot were thinned to four seedlings per pot and irrigated by $200 \mathrm{ml} \mathrm{NaCl}$ irrigation treatment once time every two days.

Plant sampling: Plants were collected two times: at 20 days after sowing ( 3 replicates) and at 27 days after sowing (3 replicates). These plants were washed by tap water then by distilled water (Hewitt, 1966), separated into leaves and root and their fresh weights were measured. One third of these fresh plant organs were preserved in the refrigerator for biochemical analysis and the other two-thirds were oven-dried at $65^{\circ} \mathrm{C}$ for $48 \mathrm{hrs}$ and their weights were measured. The oven-dried plant materials were ground using stainless steel mill and preserved for analysis.

\section{Plant Analysis:}

Growth characters: The shoot height of plant was measured and the result was expressed as $\mathrm{cm}_{\text {plant }}{ }^{-1}$. The leaf area was measured, using the fresh plant, by disk method (Radford, 1967) and the result was expressed as $\mathrm{cm}^{2}$ plant $^{-1}$. The relative growth rate (RGR) was calculated according to Radford (1976).

Elements analysis: One-tength gram oven-dried plant material was subjected to wet digestion $\left(\mathrm{H}_{2} \mathrm{SO}_{4} / \mathrm{H}_{2} \mathrm{O}_{2}\right)$ according to Cottonie (1980). The concentrations of $\mathrm{Ca}^{2+}$ and $\mathrm{Mg}^{2+}$ were determined by versenate method (Chapman and Pratt, 1961) and the concentrations of $\mathrm{Na}^{+}$and $\mathrm{K}^{+}$were measured by flame photometer (Chapman and Pratt, 1961).

Antioxidative enzyme assay: Leaves and root, of the fresh materials $(0.5$ gram), were homogenized, using tissue homogenizer, in $4 \mathrm{ml}$ ice-cold 100 $\mathrm{mM} \mathrm{K}$-phosphate buffer $(\mathrm{pH}=7.0)$ containing $0.1 \mathrm{mM}$ ethylene diamine tetra acetic acid (EDTA) and 1\% polyvinylpyrrolindone (PVP). The homogenate was filtered through muslin cloth and centrifuged at $16000 \mathrm{rpm}$ for $15 \mathrm{mins}$. 
The supernatent fraction was used as a crude extract for measuring enzyme activity. All the analytical steps were carried out at $4^{\circ} \mathrm{C}$ (Azevedo-Neto et al., 2006). The concentration of the crude extract was measured by the method described by Bradford (1976).

Total catalase (EC.1.11.1.6) activity was assayed by adding $50 \mu \mathrm{l}$ enzymatic extract to $3 \mathrm{ml}$ solution of $50 \mathrm{mM} \mathrm{K}$-phosphate buffer of $\mathrm{pH} 7$ and $20 \mathrm{mM} \mathrm{H}_{2} \mathrm{O}_{2}$. The decrease in absorbance at $240 \mathrm{~nm}$ was measured for 1 min. at $30^{\circ} \mathrm{C}$ (Havir and Mchale, 1987). The enzyme activity was calculated using the molar extinction coefficient of $36 \mathrm{M}^{-1} \mathrm{~cm}^{-1}$ and expressed as $\mu \mathrm{M}$ $\mathrm{H}_{2} \mathrm{O}_{2}$ min $^{-1} \mathrm{mg}^{-1}$ protein.

Total guaiacol peroxidase (EC.1.11.1.7) activity was assayed by adding $37 \mu \mathrm{l}$ enzyme extract to $3 \mathrm{ml}$ reaction mixture containing $50 \mathrm{mM} \mathrm{K}$ -

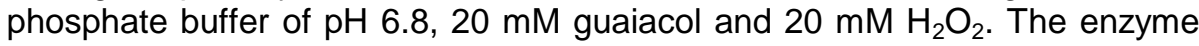
activity was quantified using the tetraguaiacol molar extinction coefficient (26.6 $\mathrm{mM}^{-1} \mathrm{~cm}^{-1}$ )and the result was expressed as $\mu \mathrm{M} \mathrm{H}_{2} \mathrm{O}_{2} \mathrm{~min}^{-1} \mathrm{mg}^{-1}$ protein (Plewa et al., 1991).

Total ascorbate peroxidase (EC.1.11.1.11) activity was assayed according to Nakano and Asada (1981). The reaction mixture $(3 \mathrm{ml})$ contained $50 \mathrm{mM}$ K-phosphate buffer $(\mathrm{pH}=7.0), 0.1 \mathrm{mM}$ EDTA, $0.5 \mathrm{mM}$ ascorbate, $1.2 \mathrm{mM} \mathrm{H}_{2} \mathrm{O}_{2}$ and $0.1 \mathrm{ml}$ enzyme extract. The enzyme activity was quantified using the molar extinction coefficient for ascorbate $\left(2.8 \mathrm{mM}^{-1} \mathrm{~cm}^{-1}\right)$ and the result was expressed as $\mu \mathrm{M} \mathrm{H}_{2} \mathrm{O}_{2}$ min $^{-1} \mathrm{mg}^{-1}$ protein (Mckersie and Leshem, 1994).

\section{Statidtical Analysis:}

The data obtained were statistically analyzed for the least significant difference (LSD) using SAS statistical analysis software (SAS Inst., 1985).

\section{RESULTS AND DISCUSSION}

\section{Growth Characters:}

Plant weight: Table 1 showed significant decrease in the fresh and dry weight (F.W. and D.W.) of leaves and root of 20 and 27 days after sowing (DAS) pea plant with increasing $\mathrm{NaCl}$ concentration treatments. As shown in Table 2, the values of the relative decrease in the F.W. of 20 DAS plants were almost higher in root than in leaves at each level of $\mathrm{NaCl}$ treatment. This indicates higher relative reduction in the growth of root than of leaves as a result of increasing salinity at this plant age. For 27 DAS plants, these values on F.W. basis were higher in root than in leaves while on D.W. basis these values were higher in leaves than in root except with $100 \mathrm{mM} \mathrm{NaCl}$ treatment.

It is also clear from Table 2 that the values of the relative decrease in leaves and root, on F.W. and D.W. basis, were almost higher in older than younger plants. These data reveal that the magnitude of reduction in the growth of pea plant, due to salt stress, would be increased with proceeding plant age. 
Table 1: The weight of leaves and root $\left(\right.$ g. plant $\left.^{-1}\right)$ shoot height $(\mathrm{cm}$ plant $\left.{ }^{-1}\right)$ and leaf area $\left(\mathrm{cm}^{2}\right.$ plant $\left.^{-1}\right)$ of pea plant at 20 and 27 DAS as influenced by $\mathrm{NaCl}$ concentration treatments.

\begin{tabular}{|l|c|c|c|c|c|c|c|c|}
\hline \multirow{2}{*}{$\begin{array}{c}\text { NaCl } \\
(\mathbf{m M})\end{array}$} & \multicolumn{2}{c|}{ Leaves } & \multicolumn{2}{c|}{ Root } & \multicolumn{2}{c|}{ L/R ratio } & $\begin{array}{c}\text { Shoot } \\
\text { height }\end{array}$ & \multicolumn{2}{c|}{$\begin{array}{c}\text { Leaf } \\
\text { area }\end{array}$} \\
\cline { 2 - 9 } & F.W. & D.W. & F.W. & D.W. & F.W. & D.W. & 20 DAS \\
\hline $\mathbf{0}$ & $0.96 \mathrm{a}$ & $0.075 \mathrm{a}$ & $1.48 \mathrm{a}$ & $0.070 \mathrm{a}$ & $0.65 \mathrm{c}$ & $1.07 \mathrm{a}$ & $6.2 \mathrm{a}$ & $28.77 \mathrm{a}$ \\
$\mathbf{2 5}$ & $0.84 \mathrm{~b}$ & $0.071 \mathrm{a}$ & $1.16 \mathrm{~b}$ & $0.063 \mathrm{a}$ & $0.72 \mathrm{a}$ & $1.13 \mathrm{a}$ & $5.6 \mathrm{~b}$ & $24.66 \mathrm{~b}$ \\
$\mathbf{5 0}$ & $0.72 \mathrm{~b}$ & $0.059 \mathrm{~b}$ & $0.97 \mathrm{~b}$ & $0.053 \mathrm{~b}$ & $0.74 \mathrm{a}$ & $1.11 \mathrm{a}$ & $5.1 \mathrm{c}$ & $20.25 \mathrm{c}$ \\
$\mathbf{7 5}$ & $0.69 \mathrm{~b}$ & $0.052 \mathrm{~b}$ & $1.00 \mathrm{~b}$ & $0.045 \mathrm{~b}$ & $0.69 \mathrm{~b}$ & $1.16 \mathrm{a}$ & $4.8 \mathrm{c}$ & $176.74 \mathrm{~d}$ \\
$\mathbf{1 0 0}$ & $0.44 \mathrm{c}$ & $0.039 \mathrm{c}$ & 0.62 & $0.036 \mathrm{c}$ & $0.71 \mathrm{a}$ & $1.08 \mathrm{a}$ & $4.2 \mathrm{~d}$ & $11.87 \mathrm{e}$ \\
\hline $\mathbf{L S D}_{\mathbf{0 . 0 5}}$ & 0.15 & 0.015 & 0.21 & 0.010 & 0.06 & 0.15 & 0.6 & 2.44 \\
\hline \multicolumn{7}{|c|}{$\mathbf{2 7 D A S}$} \\
\hline $\mathbf{0}$ & $2.19 \mathrm{a}$ & $0.214 \mathrm{a}$ & $3.41 \mathrm{a}$ & $0.165 \mathrm{a}$ & $0.64 \mathrm{~b}$ & $1.30 \mathrm{~b}$ & $10.3 \mathrm{a}$ & $73.56 \mathrm{a}$ \\
$\mathbf{2 5}$ & $1.75 \mathrm{~b}$ & $0.149 \mathrm{~b}$ & $2.47 \mathrm{~b}$ & $0.124 \mathrm{~b}$ & $0.71 \mathrm{a}$ & $1.20 \mathrm{c}$ & $8.4 \mathrm{~b}$ & $51.55 \mathrm{~b}$ \\
$\mathbf{5 0}$ & $1.34 \mathrm{c}$ & $0.113 \mathrm{c}$ & $2.01 \mathrm{c}$ & $0.094 \mathrm{c}$ & $0.67 \mathrm{a}$ & $1.20 \mathrm{c}$ & $7.1 \mathrm{c}$ & $38.03 \mathrm{c}$ \\
$\mathbf{7 5}$ & $1.14 \mathrm{c}$ & $0.086 \mathrm{~d}$ & $1.64 \mathrm{c}$ & $0.071 \mathrm{c}$ & $0.70 \mathrm{a}$ & $1.21 \mathrm{c}$ & $6.3 \mathrm{~d}$ & $29.69 \mathrm{~d}$ \\
$\mathbf{1 0 0}$ & $0.86 \mathrm{~d}$ & $0.060 \mathrm{~d}$ & $1.22 \mathrm{~d}$ & $0.042 \mathrm{~d}$ & $0.71 \mathrm{a}$ & $1.43 \mathrm{a}$ & $5.5 \mathrm{e}$ & $20.06 \mathrm{e}$ \\
\hline $\mathbf{L S D}_{\mathbf{0 . 0 5}}$ & 0.21 & 0.015 & 0.24 & 0.026 & 0.05 & 0.18 & 0.6 & 7.39 \\
\hline
\end{tabular}

Table 2: The relative decrease (\%) in the weight of leaves and root, shoot height and leaf area of pea plant at 20 and 27 DAS as influenced by $\mathrm{NaCl}$ concentration treatment.

\begin{tabular}{|c|c|c|c|c|c|c|}
\hline \multirow{2}{*}{$\begin{array}{l}\mathrm{NaCl} \\
(\mathrm{mM})\end{array}$} & \multicolumn{2}{|c|}{ Leaves } & \multicolumn{2}{|c|}{ Root } & \multirow{2}{*}{$\begin{array}{l}\text { Shoot } \\
\text { height }\end{array}$} & \multirow{2}{*}{$\begin{array}{l}\text { Leaf } \\
\text { area }\end{array}$} \\
\hline & F.W. & D.W. & F.W. & D.W. & & \\
\hline \multicolumn{7}{|c|}{20 DAS } \\
\hline 25 & 12.50 & 5.33 & 21.62 & 10.00 & 9.68 & 14.27 \\
\hline 50 & 25.00 & 21.33 & 34.46 & 24.29 & 17.74 & 29.61 \\
\hline 75 & 28.13 & 30.61 & 32.43 & 35.71 & 22.58 & 38.33 \\
\hline 100 & 54.17 & 48.00 & 58.11 & 48.57 & 32.26 & 58.72 \\
\hline Mean & 29.95 & 26.32 & 36.66 & 29.64 & 20.57 & 35.23 \\
\hline \multicolumn{7}{|c|}{27 DAS } \\
\hline 25 & 20.09 & 30.37 & 27.57 & 24.85 & 18.45 & 18.64 \\
\hline 50 & 38.81 & 47.20 & 41.06 & 43.03 & 31.07 & 38.89 \\
\hline 75 & 47,95 & 59.81 & 51.91 & 56.97 & 38.83 & 47.29 \\
\hline 100 & 60.73 & 71.96 & 64.22 & 74.55 & 46.60 & 60.09 \\
\hline Mean & 41.90 & 52.34 & 46.19 & 49.85 & 33.74 & 41.23 \\
\hline
\end{tabular}

Table 1 showed significant increase in the values of $L / R$ ratio of 20 and 27 DAS plants, on F.W. and D.W. basis, with increasing salinity. These ratios, on F.W. basis, were almost less than unity which indicate higher relative root F.W. than leaves F.W. On the other hand, on D.W. basis, there were no significant variations in the values of L/R ratio of 20 DAS plant with increasing salinity, while for 27 DAS plants these; values significantly increased with increasing salinity from 1.30 (the control plant) to 1.43 (100 $\mathrm{mM} \mathrm{NaCl}$ treated plant).

It is clear from Table 1 that L/R, on D.W. basis, were almost higher in older than younger plants. These data point out to relatively higher reduction in the growth of root than that of leaves with both increasing salinity and proceeding plant age. This indicates higher sensitivity of root to salinity than leaves and this sensitivity increased with proceeding plant age.

Table 3 showed significant decrease in the values of relative growth rate (RGR) of leaves and root, on both F.W. and D.W. basis, with increasing 
$\mathrm{NaCl}$ concentration treatments. It is also clear that, on D.W. basis, the RGR was markedly higher in leaves that in root at each level of $\mathrm{NaCl}$ treatment.

Table3: The relative growth rate $\left(\mathrm{g} \cdot \mathrm{g}^{-1}\right.$ day) of leaves and root of pea plant as influenced by $\mathrm{NaCl}$ concentration treatments.

\begin{tabular}{|l|l|l|l|l|}
\hline \multirow{2}{*}{ NaCl (mM) } & \multicolumn{2}{|c|}{ Leaves } & \multicolumn{2}{c|}{ Root } \\
\cline { 2 - 5 } & F.W. & D.W. & F.W. & D.W. \\
\hline $\mathbf{0}$ & 0.18 & 0.022 & 0.32 & 0.014 \\
$\mathbf{2 5}$ & 0.13 & 0.011 & 0.19 & 0.009 \\
$\mathbf{5 0}$ & 0.09 & 0.008 & 0.15 & 0.006 \\
$\mathbf{7 5}$ & 0.06 & 0.005 & 0.09 & 0.004 \\
$\mathbf{1 0 0}$ & 0.06 & 0.003 & 0.09 & 0.001 \\
\hline Mean & 0.10 & 0.010 & 0.17 & 0.007 \\
\hline
\end{tabular}

It can be reported that, on D.W. basis, the lower value of RGR of root (relative decrease of $92.9 \%$ ) with $100 \mathrm{mM} \mathrm{NaCl}$ treatment as compared to that of leaves (relative decrease of 86.4) denotes that the growth of root has been reduced by salinity more than leaves. This reveals that the root of pea plant is more sensitive to salinity than leaves at each level of $\mathrm{NaCl}$ treatment. Moisture content: Table 4 showed marked decrease in moisture content in leaves and root of 20 and 27 DAS plants with increasing $\mathrm{NaCl}$ concentration treatments. Also, the levels of moisture content were almost higher in root than in leaves and were higher in those of older than younger plants, at each level of $\mathrm{NaCl}$ treatment. These data point out to a negative relationship between moisture content in both leaves and root of pea plant and the levels of $\mathrm{NaCl}$ treatments. Thus, there is a positive relationship between water deficit in plant organs and salinity of the growth medium. This can be achieved by studying the data of the relative decrease in moisture content with salinity as given in Table 4 . These data clearly showed that the relative decrease in moisture content was higher in root than in leaves and was higher in older than younger plant.

Table 4: The moisture content (g. plant $\left.{ }^{-1}\right)$ and its relative decrease (\%) in leaves and root of pea plant at 20 and 27 DAS as influenced by $\mathrm{NaCl}$ concentration treatments.

\begin{tabular}{|l|c|c|c|c|}
\hline \multirow{2}{*}{ NaCl (mM) } & \multicolumn{2}{|c|}{ Leaves } & \multicolumn{2}{c|}{ Root } \\
\cline { 2 - 5 } & F.W. & D.W. & F.W. & D.W. \\
\hline $\mathbf{0}$ & 0.885 & 1.410 & - & - \\
$\mathbf{2 5}$ & 0.769 & 1.097 & 13.11 & 22.20 \\
$\mathbf{5 0}$ & 0.661 & 0.917 & 25.31 & 34.97 \\
$\mathbf{7 5}$ & 0.638 & 0.955 & 27.91 & 32.27 \\
$\mathbf{1 0 0}$ & 0.401 & 0.584 & 54.69 & 58.58 \\
\hline \multicolumn{5}{|c|}{$\mathbf{3}$} \\
\hline $\mathbf{0}$ & 1.976 & 3.245 & - & - \\
$\mathbf{2 5}$ & 1.601 & 2.346 & 18.98 & 27.90 \\
$\mathbf{5 0}$ & 1.227 & 1.916 & 37.91 & 40.96 \\
$\mathbf{7 5}$ & 1.054 & 1.569 & 46.66 & 51.65 \\
$\mathbf{1 0 0}$ & 0.800 & 1.178 & 59.51 & 63.70 \\
\hline
\end{tabular}

These results point out to the dehydration of plant organs with increasing salinity. This data can provide an explanation about the progressive reduction in the growth of pea plant under salt-stress. 
Shoot height: Table 1 showed significant decrease in the shoot height of both 20 and 27 DAS plants with increasing salinity. As shown in Table 2, there were higher values of the relative decrease in shoot height of 27 DAS plant than that those of 20 DAS plant at each level of $\mathrm{NaCl}$ treatment. In addition, the values of the relative decrease in shoot height had increased with increasing salinity for both 20 and 27 DAS plants. These data indicate that pea plant grown under salt-stress is usually stunted and shows dwarfism morphological appearance as compared to plant grown under non-saltstress.

Leaf area: Table 1 showed significant decrease in leaf area per plant with increasing $\mathrm{NaCl}$ concentration treatments for both 20 and 27 DAS plants. The relative reductions in leaf area were almost higher in older than younger plant at each level of $\mathrm{NaCl}$ treatment (Table 2). It has been reported that reduction in leaf, due to salt stress, is eventually associated with low rate of net assimilation of $\mathrm{CO}_{2}$ and consequently low plant biomass (Marschner, 1990).

\section{Element Concentration:}

Sodium: The concentration of $\mathrm{Na}^{+}$in leaves and root of 20 and 27 DAS plants has been increased with increasing $\mathrm{NaCl}$ concentration treatments and was higher in older than younger plant (Table 5). In the case of 20 DAS plant, the values of the relative increase in $\mathrm{Na}^{+}$concentration were lower in leaves (67.2, $103.2,125.4$ and $162.7 \%$ with a mean value of $114.6 \%$ ) than in root $(74.5,110.2,142.3$ and $148.2 \%$ with a mean value of $118.8 \%)$ while those of 27 DAS plant were opposite, and were higher in leaves 223.5, 329.4, 313.2 and $358.8 \%$ with a mean value of $306.2 \%)$ than in toot $(105.3,173.7,210.5$ and $236.1 \%$ with a mean value of $181.4 \%$ ) with $25,50,75$ and $100 \mathrm{mM} \mathrm{NaCl}$ concentration treatments, respectively. These data point out to increasing $\mathrm{Na}^{+}$concentration in leaves with proceeding plant age. In addition, there was a positive relationship between the relative increase of $\mathrm{Na}^{+}$concentration in plant organs and the relative decrease of D.W. of these organs.

Table 5: The concentration of $\mathrm{Na}, \mathrm{K}, \mathrm{Mg}$ and $\mathrm{Ca}\left(\mathrm{mg}^{-1} \mathrm{~g}^{-1}\right)$ in leaves (L) and root (R) of pea plant at 20 and 27 DAS as influenced by $\mathrm{NaCl}$ concentration treatments.

\begin{tabular}{|c|c|c|c|c|c|c|c|c|}
\hline \multirow{2}{*}{$\begin{array}{l}\mathrm{NaCl} \\
(\mathrm{mM})\end{array}$} & \multicolumn{2}{|c|}{$\mathrm{Na}$} & \multicolumn{2}{|c|}{$\mathrm{K}$} & \multicolumn{2}{|c|}{ Mg } & \multicolumn{2}{|c|}{$\mathrm{Ca}$} \\
\hline & $\mathbf{L}$ & $\mathbf{R}$ & $\mathbf{L}$ & $\mathbf{R}$ & $\mathbf{L}$ & $\mathbf{R}$ & $\mathbf{L}$ & $\mathbf{R}$ \\
\hline \multicolumn{9}{|c|}{20 DAS } \\
\hline 0 & $6.7 c$ & $13.7 c$ & $25.4 a$ & $37.8 \mathrm{ab}$ & $6.4 a$ & $19.4 a$ & $20.0 a$ & $11.7 a$ \\
\hline 25 & 11.2bc & $23.9 b$ & $20.7 b$ & $41.6 a$ & $4.4 b$ & 14.2bc & 18.0 & $10.0 \mathrm{~b}$ \\
\hline 50 & 13.6ab & 28.8ab & $15.4 \mathrm{c}$ & $36.9 a b$ & $4.4 b$ & $15.6 b$ & $15.3 c$ & $8.0 \mathrm{c}$ \\
\hline 75 & 15.1ab & $33.2 \mathrm{a}$ & $18.9 b c$ & $36.5 b$ & $4.6 b$ & $13.8 \mathrm{bc}$ & $13.0 d$ & $5.7 d$ \\
\hline 100 & $17.6 a$ & $34.0 \mathrm{a}$ & $17.7 \mathrm{bc}$ & $26.0 \mathrm{c}$ & $5.6 a b$ & $11.6 \mathrm{c}$ & $13.3 d$ & $4.0 \mathrm{e}$ \\
\hline LSD $_{0.05}$ & 4.6 & 5.8 & 3.9 & 5.1 & 1.5 & 2.7 & 1.3 & 1.3 \\
\hline \multicolumn{9}{|c|}{27 DAS } \\
\hline 0 & $6.8 \mathrm{c}$ & $13.3 d$ & $26.0 \mathrm{a}$ & $47.4 a b$ & $9.8 a$ & $20.8 a$ & $28.7 a$ & $18.3 a$ \\
\hline 25 & 22.0 & $27.3 c$ & $21.3 b$ & $48.8 a$ & $9.8 a$ & $14.4 \mathrm{~b}$ & $22.0 b$ & $19.0 \mathrm{a}$ \\
\hline 50 & $29.2 a$ & $36.4 b$ & $17.7 \mathrm{c}$ & $46.1 \mathrm{ab}$ & $5.6 b$ & $14.2 \mathrm{~b}$ & $18.0 \mathrm{c}$ & $20.7 a$ \\
\hline 75 & $28.1 \mathrm{a}$ & $41.3 a$ & $17.7 \mathrm{c}$ & $41.0 \mathrm{~b}$ & $4.6 \mathrm{~b}$ & $14.8 \mathrm{~b}$ & $15.0 d$ & $11.0 \mathrm{~b}$ \\
\hline 100 & $31.2 \mathrm{a}$ & $44.7 a$ & $20.8 b$ & $32.1 \mathrm{c}$ & $6.4 b$ & $15.0 \mathrm{~b}$ & $14.0 \mathrm{~d}$ & $7.0 \mathrm{c}$ \\
\hline LSD $_{0.05}$ & 4.3 & 4.2 & 2.8 & 7.8 & 3.0 & 2.0 & 2.6 & 3.6 \\
\hline
\end{tabular}


Potassium: Table 5 showed a significant decrease in the concentrations of $\mathrm{K}^{+}$in leaves and root of 20 and 27 DAS plant with increasing salt stress. It is also clear that the concentration of $\mathrm{K}^{+}$was markedly higher in root than in leaves and was higher in older than younger plant at each level of $\mathrm{NaCl}$ treatment.

Magnesium: The concentrations of $\mathrm{Mg}^{2+}$ in leaves and root, of 20 and 27 DAS plants, significantly decreased with increasing $\mathrm{NaCl}$ concentration treatments (Table 5). Also, $\mathrm{Mg}^{2+}$ concentration was almost higher in root than in leaves and was higher in older than younger plant.

Calcium: Table 5 showed a significant decrease in the concentrations of $\mathrm{Ca}^{2+}$ in leaves and root with increasing salinity and was also markedly higher in older than younger plant. It is clear from Table 5 that $\mathrm{Ca}^{2+}$ concentration was almost higher in leaves than in root at each level of $\mathrm{NaCl}$ treatment. This trend of $\mathrm{Ca}^{2+}$ distribution between leaves and root is opposite to that of $\mathrm{Na}^{+}$, $\mathrm{K}^{+}$and $\mathrm{Mg}^{2+}$ (Table 5).

The increased concentration of $\mathrm{Na}^{+}$and the decreased concentrations of $\mathrm{K}^{+}, \mathrm{Mg}^{2+}$ and $\mathrm{Ca}^{2+}$ in leaves and root of pea plant would lead to elements-imbalance and consequently disorders of the biochemical processes in plant. This would lead to deficiency of some nutrients and reduction in plant growth (Marschner, 1990). It has been also reported that high $\mathrm{Na}^{+}$concentration and low $\mathrm{K}^{+}$concentration in plant are considered to be one of the important physiological factors contributing to the tolerance of many plant species to salt stress (Marschner, 1990).

$\mathrm{Na}_{L} / \mathrm{Na}_{\mathrm{R}}$ ration: There were no significant differences in $\mathrm{Na} / \mathrm{Na}_{\mathrm{R}}$ ratio with all levels of $\mathrm{NaCl}$ treatments for 20 DAS plants. However, this ratio significantly increased, relative to the control, for 27 DAS plant even under low salt stress (Table 6). In general, these ratios were almost less than unity which indicate lower proportion of $\mathrm{Na}^{+}$absorbed by plant has been transported from root to leaves than that accumulated in root. In addition, the higher $\mathrm{Na}_{\llcorner} / \mathrm{Na}_{\mathrm{R}}$ in older than younger plant reveal that $\mathrm{Na}^{+}$transport from root to leaves increased with proceeding plant age.

Table 6: Leaves/root (L/R) ratio of $\mathrm{Na}, \mathrm{K}, \mathrm{Mg}$ and $\mathrm{Ca}$ of pea plant at 20 and $27 \mathrm{DAS}$ as influenced by $\mathrm{NaCl}$ concentration treatments.

\begin{tabular}{|c|c|c|c|c|}
\hline $\mathrm{NaCl}(\mathrm{mM})$ & $\mathrm{Na}_{\mathrm{L} / \mathrm{NaR}}$ & $\mathrm{K}_{\mathrm{L} / \mathrm{KR}}$ & $\mathrm{Mg}_{\mathrm{L} / \mathrm{MgR}}$ & $\mathrm{Ca}_{\mathrm{L} / \mathrm{CaR}}$ \\
\hline \multicolumn{5}{|c|}{20 DAS } \\
\hline 0 & $0.49 a$ & $0.67 a$ & $0.33 b$ & $1.71 \mathrm{c}$ \\
\hline 25 & $0.47 a$ & $0.50 \mathrm{~b}$ & $0.31 b$ & $1.80 \mathrm{c}$ \\
\hline 50 & $0.47 a$ & $0.42 b$ & $0.28 b$ & $1.91 \mathrm{c}$ \\
\hline 75 & $0.46 a$ & $0.52 b$ & $0.33 b$ & $2.28 \mathrm{~b}$ \\
\hline 100 & $0.52 a$ & $0.68 a$ & $0.48 a$ & 3.33a \\
\hline LSD $_{0.05}$ & 0.27 & 0.13 & 0.14 & 0.32 \\
\hline \multicolumn{5}{|c|}{27 DAS } \\
\hline 0 & $0.51 b$ & $0.55 a b$ & $0.47 a b c$ & $1.57 a b$ \\
\hline 25 & $0.81 a$ & $0.44 b c$ & $0.68 a$ & $1.16 \mathrm{bc}$ \\
\hline 50 & $0.84 a$ & $0.38 c$ & $0.39 a b$ & $0.87 c$ \\
\hline 75 & $0.68 a$ & $0.43 \mathrm{bc}$ & $0.31 \mathrm{c}$ & $1.36 \mathrm{bc}$ \\
\hline 100 & $0.70 a$ & $0.65 a$ & $0.43 \mathrm{bc}$ & $2.00 \mathrm{a}$ \\
\hline $\mathrm{LSD}_{0.05}$ & 0.16 & 0.13 & 0.22 & 0.56 \\
\hline
\end{tabular}


$\mathrm{K}_{\mathrm{L}} / \mathrm{K}_{\mathrm{R}}$ ratio: Table 6 showed that the values of $\mathrm{K}_{\mathrm{L}} / \mathrm{K}_{\mathrm{R}}$ ratio were less than unity for both 20 and 27 DAS plants. This points out to low relative transport of $\mathrm{K}^{+}$from root to leaves and that higher proportion of $\mathrm{K}^{+}$absorbed by plant has been accumulated in root.

$\mathrm{Mg}_{\mathrm{L}} / \mathrm{Mg}_{\mathrm{R}}$ ratio: Table 6 showed that the values of $\mathrm{Mg}_{\mathrm{L}} / \mathrm{Mg}_{\mathrm{R}}$ ratio were less than unity for both 20 and 27 DAS plants. This indicates that higher proportion of $\mathrm{Mg}^{2+}$ absorbed by plant has been accumulated in root rather than transported to leaves.

$\mathrm{Ca}_{\mathrm{L}} / \mathrm{Ca}_{\mathrm{R}}$ : The values of $\mathrm{Ca}_{\llcorner} / \mathrm{Ca}_{\mathrm{R}}$ were generally more than unity which indicate that higher proportion of $\mathrm{Ca}^{2+}$ absorbed by plant has been transported from root to leaves (Table 6). There were also significant higher $\mathrm{Ca}_{\llcorner} / \mathrm{Ca}_{\mathrm{R}}$ ratios (3.33 and 2.00) with the highest $\mathrm{NaCl}$ treatment $(100 \mathrm{mM}$ $\mathrm{NaCl})$ relative to those of the control (1.71 and 1.57) for both 20 and 27 DAS plants, respectively. It is also clear from Table 6 that the values of $\mathrm{Ca}_{\mathrm{L}} / \mathrm{Ca}_{\mathrm{R}}$ ratio were higher in younger than in older plants which indicate relatively low transport of $\mathrm{Ca}^{2+}$ from root to leaves with proceeding plant age.

$\mathrm{K} / \mathrm{Na}$ ratio: Table 7 showed marked decrease in the values of $\mathrm{K} / \mathrm{Na}$ ratio in leaves and root of 20 and 27 DAS plants with increasing $\mathrm{NaCl}$ concentration treatments. These values were almost more than unity for younger plant except in root with $100 \mathrm{mM} \mathrm{NaCl}$ treatment and also were higher in leaves than in root at each $\mathrm{NaCl}$ treatment. These values out that higher proportion of $\mathrm{K}^{+}$absorbed plant has been transported from root to leaves relative to that which is accumulated in root. This trend was opposite for 27 DAS plant since higher $\mathrm{K} / \mathrm{Na}$ ratios were found in root than in leaves at each level of $\mathrm{NaCl}$ treatment. It is also clear that $\mathrm{K} / \mathrm{Na}$ ratios in leaves of 27 DAS plants treated with $25-100 \mathrm{mM} \mathrm{NaCl}$ were less than unity. This reveals that lower proportion of $\mathrm{K}^{+}$absorbed by plant has been transported from root to leaves relative to that of $\mathrm{Na}^{+}$with increasing both $\mathrm{NaCl}$ concentration treatments and plant age.

Table 7: The ratio of $\mathrm{K} / \mathrm{Na}, \mathrm{Mg} / \mathrm{Na}$ and $\mathrm{Ca} / \mathrm{Na}$ in leaves $(\mathrm{L})$ and root $(\mathrm{R})$ of pea plant at 20 and 27 DAS as influenced by $\mathrm{NaCl}$ concentration treatments.

\begin{tabular}{|c|c|c|c|c|c|c|}
\hline \multirow{2}{*}{$\mathrm{NaCl}(\mathrm{mM})$} & \multicolumn{2}{|c|}{$\mathrm{K} / \mathrm{Na}$} & \multicolumn{2}{|c|}{$\mathrm{Mg} / \mathrm{Na}$} & \multicolumn{2}{|c|}{$\mathrm{Ca} / \mathrm{Na}$} \\
\hline & $\mathbf{L}$ & $\mathbf{R}$ & $\mathbf{L}$ & $\mathbf{R}$ & $\mathbf{L}$ & $\mathbf{R}$ \\
\hline \multicolumn{7}{|c|}{20 DAS } \\
\hline 0 & 3.79 & 2.76 & 0.96 & 1.42 & 2.99 & 0.85 \\
\hline 25 & 1.88 & 1.74 & 0.39 & 0.59 & 1.61 & 0.42 \\
\hline 50 & 1.13 & 1.28 & 0.32 & 0.54 & 1.13 & 0.28 \\
\hline 75 & 1.25 & 1.10 & 0.31 & 0.42 & 0.86 & 0.17 \\
\hline 100 & 1.01 & 0.77 & 0.32 & 0.34 & 0.76 & 0.12 \\
\hline \multicolumn{7}{|c|}{27 DAS } \\
\hline 0 & 3.82 & 3.56 & 1.44 & 1.65 & 4.22 & 1.38 \\
\hline 25 & 0.97 & 1.79 & 0.46 & 0.53 & 1.00 & 0.70 \\
\hline 50 & 0.61 & 1..27 & 0.19 & 0.39 & 0.62 & 0.57 \\
\hline 75 & 0.63 & 0.99 & 0.16 & 0.36 & 0.53 & 0.27 \\
\hline 100 & 0.66 & 0.72 & 0.21 & 0.34 & 0.45 & 0.16 \\
\hline
\end{tabular}

Plants grown under non-salt-stress (the control plant) have the highest $\mathrm{K} / \mathrm{Na}$ ratio in both leaves and root of 20 and 27 DAS plants as compared to those of plants grown under salt-stress (Table 7). These values 
were more than unity and also were higher in leaves (3.79 and 3.82) than in root (2.76 and 3.36) of 20 and 27 DAS plants, respectively. This could be due mainly to selective absorption of $\mathrm{K}^{+}$by plant relative to that of $\mathrm{Na}^{+}$especially for plants grown under non-salt stress. It has been reported by Tester and Davenport (2003) that high $\mathrm{K} / \mathrm{Na}$ ratio is concomitant with high growth of leaves and root than low $\mathrm{K} / \mathrm{Na}$ ratio.

$\mathrm{Mg} / \mathrm{Na}$ ratio: Table 7 showed marked decrease in the values of $\mathrm{Mg} / \mathrm{Na}$ ratio in leaves and root of 20 and 27 DAS plants with increasing $\mathrm{NaCl}$ concentration treatments. These ratios were less than unity which indicate low $\mathrm{Mg}^{2+}$ transport from root to leaves relative to that of $\mathrm{Na}^{+}$. However, pea plant grown under non-salt stress have $\mathrm{Mg} / \mathrm{Na}$ ratio more than unity except that of leaves of 20 DAS plant. This reveals that under non-salt stress condition, leaves and root would contain relatively higher $\mathrm{Mg}^{2+}$ concentration than $\mathrm{Na}^{+}$. The higher $\mathrm{Mg} / \mathrm{Na}$ ratio in root than in leaves, at each $\mathrm{NaCl}$ concentration treatment, points out to lower transport of $\mathrm{Mg}^{2+}$ from root to leaves.

$\mathrm{Ca} / \mathrm{Na}$ ratio: There was a decrease in the values of $\mathrm{Ca} / \mathrm{Na}$ in leaves and root of 20 and 27 DAS plants with increasing salinity (Table 7). These ratios were almost higher in leaves than in root, at each level of $\mathrm{NaCl}$ treatment, which indicate relatively higher transport of $\mathrm{Ca}^{2+}$ from root to leaves relative to its accumulation in the root. Also, $\mathrm{Ca}^{2+}$ transport from root to leaves, of plants under salt-stress, were more observed in younger than in older plants as indicated by the higher $\mathrm{Ca} / \mathrm{Na}$ ratio. In addition, for younger plants, the $\mathrm{Ca} / \mathrm{Na}$ ratios were more than unity with 25 and $50 \mathrm{mM} \mathrm{NaCl}$ and also were higher in younger than older plants. This indicates relatively higher transport of $\mathrm{Ca}^{2+}$ to leaves of younger than older plants as compared to that of $\mathrm{Na}^{+}$.

Plant grown under non-salt stress had higher $\mathrm{Ca} / \mathrm{Na}$ ratio than that grown under salt-stress. This ratio was higher in leaves than in root and also was higher in older than younger plants. This indicates that plant grown under non-salt stress would contain relatively higher level of $\mathrm{Ca}^{2+}$ than of $\mathrm{Na}^{+}$.

\section{Element Uptake:}

$\mathrm{Na}^{+}$uptake: Table 8 showed significant increase in the amounts of $\mathrm{Na}^{+}$ uptake in leaves and root with $\mathrm{NaCl}$ concentration treatment up to $100 \mathrm{mM}$ $\mathrm{NaCl}$ for $20 \mathrm{DAS}$ plants and up to $75 \mathrm{mM} \mathrm{NaCl}$ for 27 DAS plants relative to the control treatment. The amounts of $\mathrm{Na}^{+}$uptake were higher in root than in leaves at each level of $\mathrm{NaCl}$ treatment.

$\mathrm{K}^{+}$uptake: It is clear from Table 8 that the amounts of $\mathrm{K}^{+}$uptake in leaves and root, of 20 and 27 DAS plants, significantly decreased with increasing $\mathrm{NaCl}$ concentrations treatments. These amounts were almost higher in root than in leaves at each level of $\mathrm{NaCl}$ treatment and were also higher in 27 DAS plants than 20 DAS plants. It is also clear from Table 8 that the highest levels of $\mathrm{K}^{+}$uptake were found in leaves and root of 20 and 27 DAS plants when grown under non-salt-stress as compared with those grown under salt stress.

$\mathrm{Mg}^{2+}$ uptake: The amounts of $\mathrm{Mg}^{2+}$ uptake in leaves and root of 20 and 27 DAS plants decreased significantly with increasing $\mathrm{NaCl}$ concentration treatments (Table 8). These amounts were almost higher in root than in 
leaves, and were also higher in older than younger plants at each level of $\mathrm{NaCl}$ treatment.

Table 8: The amount of $\mathrm{Na}, \mathrm{K}, \mathrm{Mg}$ and $\mathrm{Ca}$ uptake $\left(\mathrm{mg}^{\text {plant }}{ }^{-1}\right)$ in leaves $(\mathrm{L})$ and root $(\mathrm{R})$ of pea plant at 20 and 27 DAS as influenced by $\mathrm{NaCl}$ concentration treatments.

\begin{tabular}{|c|c|c|c|c|c|c|c|c|}
\hline \multirow{2}{*}{$\begin{array}{l}\mathrm{NaCl} \\
(\mathrm{mM})\end{array}$} & \multicolumn{2}{|c|}{$\mathrm{Na}$} & \multicolumn{2}{|c|}{$\mathrm{K}$} & \multicolumn{2}{|c|}{ Mg } & \multicolumn{2}{|c|}{$\mathrm{Ca}$} \\
\hline & $\mathbf{L}$ & $\mathbf{R}$ & $\mathbf{L}$ & $\mathbf{R}$ & $\mathbf{L}$ & $\mathbf{R}$ & $\mathbf{L}$ & $\mathbf{R}$ \\
\hline \multicolumn{9}{|c|}{20 DAS } \\
\hline 0 & $0.50 c$ & $0.96 c$ & $1.91 a$ & $2.65 a$ & $0.48 a$ & $1.36 \mathrm{a}$ & $1.50 \mathrm{a}$ & $0.82 a$ \\
\hline 25 & $0.80 a$ & $1.51 \mathrm{a}$ & $1.47 b$ & $2.62 a$ & $0.31 b$ & $0.89 b$ & $1.28 b$ & $0.63 b$ \\
\hline 50 & $0.80 a$ & $1.53 a$ & $0.91 \mathrm{c}$ & $1.96 b$ & $0.26 \mathrm{~b}$ & $0.83 b$ & $0.90 c$ & $0.42 \mathrm{c}$ \\
\hline 75 & $0.99 a$ & $1.49 a$ & $0.98 \mathrm{c}$ & $1.64 b$ & $0.24 c$ & $0.62 b c$ & $0.68 d$ & $0.26 d$ \\
\hline 100 & $0.69 b$ & $1.22 b$ & $0.66 \mathrm{~d}$ & $0.94 \mathrm{c}$ & $0.21 \mathrm{c}$ & $0.42 c$ & $0.49 e$ & $0.14 \mathrm{e}$ \\
\hline LSD $_{0.05}$ & 0.10 & 0.30 & 0.35 & 0.50 & 0.10 & 0.23 & 0.12 & 0.08 \\
\hline \multicolumn{9}{|c|}{27 DAS } \\
\hline 0 & $1.46 c$ & $2.20 c$ & $5.56 a$ & $7.82 a$ & $2.10 a$ & $3.43 a$ & $6.15 a$ & $3.02 a$ \\
\hline 25 & $3.28 a$ & $3.39 a$ & $3.17 b$ & $6.05 b$ & $1.40 \mathrm{~b}$ & $1.39 b$ & $3.28 b$ & $2.36 b$ \\
\hline 50 & $3.30 a$ & $3.42 \mathrm{a}$ & $2.00 \mathrm{c}$ & $4.33 c$ & $0.64 c$ & $1.35 b$ & $2.03 b$ & $1.95 c$ \\
\hline 75 & $2.42 b$ & $2.93 b$ & $1.52 d$ & $2.91 d$ & $0.40 \mathrm{c}$ & $1.05 b c$ & $1.29 c$ & $0.78 d$ \\
\hline 100 & $1.87 \mathrm{c}$ & $1.88 \mathrm{c}$ & $1.24 d$ & $1.35 e$ & $0.38 c$ & $0.63 c$ & $0.84 c$ & $0.29 \mathrm{e}$ \\
\hline LSD $_{0.05}$ & 0.65 & 0.44 & 0.88 & 0.95 & 0.46 & 0.72 & 0.65 & 0.42 \\
\hline
\end{tabular}

$\mathrm{Ca}^{2+}$ uptake: Table 8 showed a significant decrease in the amounts of $\mathrm{Ca}^{2+}$ uptake in leaves and root of 20 and 27 DAS plants with increasing $\mathrm{NaCl}$ concentration treatments. These amounts were higher in leaves than in root and were higher in older than younger plants, at each level of $\mathrm{NaCl}$ treatment.

\section{Antioxidative Enzyme Activity:}

Catalase (EC.I.11.1.6): Table 9 showed no significant differences between the levels of catalase (CAT) activity in leaves of 20 or 27 DAS plants treated with 25,50 and $75 \mathrm{mM} \mathrm{NaCl}$ and that of the control treatment. However, the lowest significant levels of CAT activity were found in leaves of 20 and 27 DAS plants (12.73 and $16.70 \mu \mathrm{M} \quad \mathrm{H}_{2} \mathrm{O}_{2} \cdot \mathrm{min}^{-1}$. $\mathrm{mg}^{-1}$ protein, respectively) with $100 \mathrm{mM} \mathrm{NaCl}$ treatment, which represented values of relative decrease of 20.2 and $10.4 \%$, respectively.

Tables 5 and 9 showed a negative relationship between $\mathrm{Na}^{+}$ concentration and CAT activity in leaves of either 20 or 27 DAS plants. This reveals that salinized leaves, of pea plant, exihibit relatively lower CAT activity than non-salinized leaves.

The study carried out by Tejera Garcia et al. (2007) showed significant reduction in CAT activity in leaves of salt-sensitive bean (Phaseolus vulgaris) with increasing salinity. They reported that the relative reductions in CAT activity were 40 and $75 \%$ with 25 and $50 \mathrm{mM} \mathrm{NaCl}$ treatments, respectively. Also, Kant and Turan (2011) found a significant decrease in CAT activity in root of bean (Phaseolus vulgaris L.) with increasing salinity up to $120 \mathrm{mM} \mathrm{NaCl}$. On the other hand, Wang and Han (2009) reported that CAT activity did not significantly change in leaves of saltsensitive alfalfa (Midicago sativa) cultivar subjected to 70 and $140 \mathrm{mM} \mathrm{NaCl}$ 
for 7 days, relative to that in leaves of the control plant. However, they found a significant reduction in leaves CAT activity with higher concentration of $\mathrm{NaCl}$ up to $210 \mathrm{mM}$.

Table 9: The activity of CAT, POD and APX enzymes $\left(\mu \mathrm{M} \mathrm{H}_{2} \mathrm{O}_{2} \cdot \mathrm{min}^{-1} \mathrm{mg}^{-}\right.$ ${ }^{1}$ protein) in leaves (L) and root (R) of pea plant at 20 and 27 DAS as influenced by $\mathrm{NaCl}$ concentration treatments.

\begin{tabular}{|c|c|c|c|c|c|c|}
\hline \multirow{2}{*}{$\mathrm{NaCl}(\mathrm{mM})$} & \multicolumn{2}{|c|}{ CAT } & \multicolumn{2}{|c|}{ POD } & \multicolumn{2}{|c|}{ APX } \\
\hline & $\mathbf{L}$ & $\mathbf{R}$ & $\mathbf{L}$ & $\mathbf{R}$ & $\mathbf{L}$ & $\mathbf{R}$ \\
\hline \multicolumn{7}{|c|}{20 DAS } \\
\hline 0 & $15.95 a$ & $9.42 a$ & $102.5 b$ & $1785 a$ & $28.31 \mathrm{a}$ & $45.89 a$ \\
\hline 25 & $14.52 \mathrm{a}$ & 8.52ab & $95.9 \mathrm{~b}$ & $1543 b$ & $24.21 b$ & $39.83 b$ \\
\hline 50 & $15.05 a$ & $10.99 a$ & $71.1 \mathrm{c}$ & $1601 b$ & $27.19 a$ & $42.64 a$ \\
\hline 75 & $15.74 a$ & 8.67ab & $119.5 a$ & $1865 a$ & $22.82 b c$ & $39.48 b$ \\
\hline 100 & $12.73 c$ & $7.13 c$ & $132.3 a$ & $1894 a$ & $18.72 \mathrm{c}$ & $33.48 c$ \\
\hline LSD $_{0,05}$ & 2.54 & 1.40 & 17.3 & 166 & 3.82 & 5.14 \\
\hline \multicolumn{7}{|c|}{27 DAS } \\
\hline 0 & $18.64 a$ & $12.15 a$ & $103.4 b$ & $2749 a$ & $24.18 a$ & $58.14 a$ \\
\hline 25 & $18.82 a$ & $10.96 \mathrm{ab}$ & $105.3 b$ & $2176 b$ & $20.31 b$ & $51.11 b$ \\
\hline 50 & 19.30a & $11.75 a$ & 117.1a & $2106 b$ & $23.79 a$ & $58.47 a$ \\
\hline 75 & $18.29 a$ & $8.62 b c$ & 111.1ab & $1864 c$ & $17.85 b c$ & $45.26 b$ \\
\hline 100 & $16.70 \mathrm{c}$ & $7.99 c$ & $100.0 \mathrm{~b}$ & $1778 \mathrm{c}$ & $14.05 c$ & $38.88 c$ \\
\hline LSD $_{0.05}$ & 2.60 & 1.55 & 12.0 & 175 & 2.52 & 6.15 \\
\hline
\end{tabular}

It is clear from Table 10 that the mean level of CAT activity was significantly higher in leaves of older than younger plant. However, Tejera Garcia et al. (2007) found a decrease in the activity of CAT in leaves of bean (Phaseolus vulgaris) with increasing age of plant up to 30 DAS which is opposite to our finding in the present study.

Table 10: The mean value of the activity of CAT, POD and APX enzymes $\left(\mu \mathrm{M} \mathrm{H}_{2} \mathrm{O}_{2} \cdot \mathrm{min}^{-1} \mathrm{mg}^{-1}\right.$ protein) in leaves $(L)$ and root $(R)$ of pea plant as influenced by plant age.

\begin{tabular}{|l|c|c|c|c|c|c|}
\hline \multirow{2}{*}{$\begin{array}{c}\text { Plant age } \\
\text { (DAS) }\end{array}$} & \multicolumn{2}{|c|}{ CAT } & \multicolumn{2}{c|}{ POD } & \multicolumn{2}{c|}{ APX } \\
\cline { 2 - 7 } & $\mathbf{L}$ & $\mathbf{R}$ & $\mathbf{L}$ & $\mathbf{R}$ & $\mathbf{L}$ & $\mathbf{R}$ \\
\hline $\mathbf{2 0}$ & $14.39 \mathrm{~b}$ & $9.03 \mathrm{~b}$ & $104.2 \mathrm{a}$ & $1735 \mathrm{~b}$ & $24.05 \mathrm{a}$ & $40.16 \mathrm{~b}$ \\
$\mathbf{2 7}$ & $18.13 \mathrm{a}$ & $10.29 \mathrm{a}$ & $107.4 \mathrm{a}$ & $2135 \mathrm{a}$ & $19.72 \mathrm{~b}$ & $50.39 \mathrm{a}$ \\
\hline LSD $_{0.05}$ & 2.27 & 1.25 & 15.3 & 214 & 3.42 & 5.80 \\
\hline
\end{tabular}

Table 9 showed that the highest significant levels of CAT activity were found in root of 20 or 27 DAS plant with $50 \mathrm{mM} \mathrm{NaCl}$ treatment (10.99 or $11.75 \mu \mathrm{M} \mathrm{H}_{2} \mathrm{O}_{2}$. $\mathrm{min}^{-1}$. $\mathrm{mg}^{-1}$ protein, respectively) and in root of the control plant (9.42 or $12.15 \mu \mathrm{M} \mathrm{H}_{2} \mathrm{O}_{2}$. $\mathrm{min}^{-1}$. $\mathrm{mg}^{-1}$ protein, respectively). On the other hand, the lowest significant levels of CAT activity were found in root of 20 and 27 DAS plants ( 7.13 and $7.99 \mu \mathrm{M} \mathrm{H}_{2} \mathrm{O}_{2}$. $\mathrm{min}^{-1}$. $\mathrm{mg}^{-1}$ protein, respectively) with $100 \mathrm{mM} \mathrm{NaCl}$ treatment, which represented values of relative reduction in CAT activity of 24.3 and $34.2 \%$, respectively. These data point out to relatively higher reduction in the activity of CAT enzyme in root of pea plant with both high salinity and proceeding plant age.

Tables 5 and 9 showed a negative relationship between $\mathrm{Na}^{+}$ concentration and CAT activity in root of 20 or 27 DAS plants. 
The data presented in Tables 9 and 10 showed higher levels of CAT activity in leaves than in root. This can be clearly noticed at each level of $\mathrm{NaCl}$ treatment (Table 9).

The study carried out by Tejera Garcia et al. (2007) suggested that CAT activity in salt-sensitive legumes would be deminished under salt stress and that the detoxifying role of the enzyme should be limited under such conditions. Thus, the data obtained in the present study, therefore, may support the assumption concerning the possibility of direct inhibition of CAT enzyme by $\mathrm{NaCl}$ in salt-sensitive plant.

Peroxidase (EC.1.11.1.7): Table 9 showed that the highest significant levels of peroxidase enzyme (POD) activity in leaves of 20 DAS plant were found with 75 and $100 \mathrm{mM} \mathrm{NaCl}$ treatments (119.5 and $132.3 \mu \mathrm{M} \mathrm{H}_{2} \mathrm{O}_{2} \cdot \mathrm{min}^{-1}$. $\mathrm{mg}^{-1}$ protein, respectively). These levels represented relative increases in POD activity of 16.6 and $29.1 \%$, respectively. On the other hand, the lowest significant level of $P O D$ activity in leaves was found with $50 \mathrm{mM} \mathrm{NaCl}$ treatment $\left(71.1 \mu \mathrm{M} \mathrm{H}_{2} \mathrm{O}_{2}\right.$. $\mathrm{min}^{-1}$. $\mathrm{mg}^{-1}$ protein) which represented relative reduction of $30.6 \%$.

In the case of 27 DAS plant, the highest significant level of POD activity in leaves occurred with $50 \mathrm{mM} \mathrm{NaCl}$ treatment, which represented a relative increase of $13.3 \%$. However, there were no significant variations between POD activities in leaves with 25 and $100 \mathrm{mM} \mathrm{NaCl}$ treatments and the control.

Tables 5 and 9 showed a positive relationship between $\mathrm{Na}^{+}$ concentration and POD activity in leaves of 20 DAS plant while in those of 27 DAS plant this relation was not clear.

It is clear from Table 10 that there was no significant difference between POD activity in leaves of the younger and old plants.

Wang and Han (2009) found a significant increase in POD activity in leaves of salt-sensitive alfalfa cultivar with increasing salinity from 70 to 210 $\mathrm{mM} \mathrm{NaCl}$ as compared to the control. Also, Kant and Turan (2011) found an increase of POD activity in leaves of bean with increasing salinity up to 120 $\mathrm{mM} \mathrm{NaCl}$.

Table 9 showed no significant differences between POD activity in root of 20 DAS plants treated with 75 and $100 \mathrm{mM} \mathrm{NaCl}$ and that of the control. However, the lowest significant levels of POD activity in root were found with 25 and $50 \mathrm{mM} \mathrm{NaCl}$ treatments which represented relative reductions of 13.6 and $10.3 \%$, respectively. In the case of 27 DAS plant, the lowest POD activities in root were found with 75 and $100 \mathrm{mM} \mathrm{NaCl}$ treatments which represented relative reductions of 32.2 and $35.3 \%$, respectively.

Tables 5 and 9 showed a negative relationship between the concentration of $\mathrm{Na}^{+}$and the activity of POD in root of 27 DAS plants. These data reveal that high salinity $(100 \mathrm{mM} \mathrm{NaCl})$ had inhibited the activity of POD enzyme in the root of 27 DAS plant while it did not significantly affect POD activity in root of 20 DAS plant. The study carried out by Jebara et al. (2005), however, showed that under salt stress $(50 \mathrm{mM} \mathrm{NaCl})$ the POD activity in root of bean (Phaseolus vulgaris genotype PAT 474) was increased relative to that of the control. 
Table 10 showed that the POD activity was significantly higher in root of older than younger plant. Also, Tables 9 and 10 showed that the POD activity was markedly higher in root than in leaves, at each level of $\mathrm{NaCl}$ treatment.

Ascorbate Peroxidase (EC.1.11.1.11): As shown in Table 9, the lowest significant levels of ascorbate peroxidase (APX) activity, in leaves of 20 and 27 DAS plants, were due to $100 \mathrm{mM} \mathrm{NaCl}$ treatment. These levels were 18.72 and $14.05 \mu \mathrm{M} \mathrm{H}_{2} \mathrm{O}_{2}$. $\mathrm{min}^{-1}$. $\mathrm{mg}^{-1}$ protein, and represented values of relative reduction in the enzyme activity of 33.9 and $41.5 \%$, respectively. This points out that high salinity $(100 \mathrm{mM} \mathrm{NaCl})$ has inhibited APX enzyme in leaves of pea plant grown under salt stress. Also, there was a high relative reduction in the activity of APX enzyme in leaves with proceeding plant age.

Studies carried out by Hernandez et al. (2001) \& Hernandez and Almansa (2002) showed that there were no significant changes in the activity of APX in leaves of salt-sensitive pea plant with increasing salinity. However, in earlier study, Hernandez et al. (2000) found that the activity of APX in leaves of pea plant had significantly increased with increasing salinity. In addition, Wang and Han (2009) found higher levels of APX activity in leaves of salt-sensitive alfalfa (Medicago sativa) cultivar grown under salt stress relative to the control. They reported that salt-sensitive alfalfa cultivar may mainly employ APX for detoxification of $\mathrm{H}_{2} \mathrm{O}_{2}$ in leaves of plant under salt stress $(210 \mathrm{mM} \mathrm{NaCl})$.

Examining the data in Tables 5 and 9 showed that there was a negative relationship between the concentration of $\mathrm{Na}^{+}$and the activity of APX enzyme in leaves of either 20 or 27 DAS plants.

Table 10 showed that the level of APX activity was significantly higher in leaves of older than younger plants. This is clearly observed at each level of $\mathrm{NaCl}$ treatment (Table 9).

Table 9 showed that the highest significant levels of APX activity were found in root of the control plants (45.89 and $58.14 \mu \mathrm{M} \mathrm{H}_{2} \mathrm{O}_{2} \cdot \mathrm{min}^{-1}$. $\mathrm{mg}^{-1}$ protein for 20 and 27 DAS plants, respectively). The lowest significant levels of APX activity in root were found with $100 \mathrm{mM} \mathrm{NaCl}$ treatment (33.48 and $38.88 \mu \mathrm{M} \mathrm{H}_{2} \mathrm{O}_{2}$. min $^{-1} \mathrm{mg}^{-1}$ protein for 20 and 27 DAS plants, respectively) which represented values of relative reduction in APX activity of 27.0 and $33.1 \%$, respectively. However, Jebara et al. (2005) found that the activity of APX enzyme in root of bean (Phaseolus vulgaris genotype BAT 477) had increased when the plant was grown under salt stress $(50 \mathrm{mM} \mathrm{NaCl})$ relative to the control plant.

Tables 5 and 9 showed a negative relationship between the concentration of $\mathrm{Na}^{+}$and the activity of APX enzyme in root of either 20 or 27 DAS plants.

It is clear also from Table 10 that the activity of APX was significantly higher in root of older than younger plant. This is markedly clear at each level of $\mathrm{NaCl}$ treatment (Table 9). It is also clear that APX activity was markedly higher in root than in leaves of pea plant at each level of $\mathrm{NaCl}$ treatment (Table 9). 


\section{Conclusion}

Accumulation of $\mathrm{Na}^{+}$in leaves and root of pea (Pisum sativum) plant grown under salt stress was associated with low growth of plant and low concentrations of $\mathrm{K}^{+}, \mathrm{Mg}^{2+}$ and $\mathrm{Ca}^{2+}$. This elements imbalance led to inhibition of the enzymes (CAT and APX) in both leaves and root of 20 and 27 DAS plants. The relative increases of enzymes inhibition were higher in older than younger plants. On the other hand, the activity of POD enzyme in leaves of the younger plant had increased with increasing salinity but did not change in leaves of older plant. In addition, POD activity did not change in root of younger plant with increasing salinity but decreased in root of older plant.

Several studies suggested that the decrease in the activity of antioxidative enzymes (CAT, POD and APX) usually occurred in plant which can be considered salt-sensitive. This was mostly associated with high concentrations of $\mathrm{Na}^{+}$and low concentrations of $\mathrm{K}^{+}, \mathrm{Mg}^{2+}$ and $\mathrm{Ca}^{2+}$ in leaves and root of the plant.

\section{REFERENCES}

Ahmadi, A., Eman, Y. and Pessarakli, M. (2009) Response of various cultivars of wheat and maize to salinity stress. J. Food Agric. Environ. 7:123-128.

Azevedo Neto, A.D., Prisco. J.T., Eneas-Filho, J., Abreu, C.E.B. and GomesFilho, E. (2006) Effect of salt stress on antioxidative enzymes and lipid peroxidation in leaves and roots of salt-tolerant and salt-sensitive maize genotypes. Environ. Exp. Bot. 56: 87-94.

Bradford, M.M. (1976) A rapid and sensitive method for the quantification of microgram quantities of proteins utilizing the principles of protein-dye binding. Anal. Biochem. 72: 248-254.

Chapman, H.D. and Pratt, P.F. (1961) Methods of Analysis for Soils, Plants and Water. University of California, Division of Agricultural Sciences.

Cottenie, A. (1980) Soil and Plant Testing as a Basis of Fertilizer Recommendations, FAO of the United Nations, Rome, Italy.

Dalton, D.A., Baird, L.M., Langeberg, L., Taugher, C.Y., Anyan, W.R., Vance, C.P. and Sarath, G. (1993) Subcellular localization of oxygen defense enzymes in soybean (Glycine max L. Mer) root nodules. Plant physiol. 102: 481-489.

Elsokkary, I.H., Mourad, A.Y., Abdelhady, A. and Abdallah, E.A. (2010) Response of pea (Pisum sativum L.) plant grown in sand culture under salinity stress to foliar application by kinetin and gibberillic Acid. J. Soil Sci. Agric. Engineering Mansoura Univ. 1: 1075-1087.

Havir, E.A. and Mchale, N.A. (1987) Biochemical and developmental characterization of multiple forms of catalase in tobacco leaves. Plant physiol. 84: 450-455.

Hernandez, J.A., Campillo, A., Jimenez, A., Alarcon, J.J. and Sevilla, F. (1999) Response of antioxidant systems and leaf water relation to $\mathrm{NaCl}$ stress in pea plants. New Phytol. 141: 241-251.

Hernandez, J.A., Jimenez, A., Mullineaux P., and Sevilla F. (2000) Tolerance of pea plants (Pisum sativum) to long term salt stress is associated with induction of antioxidant defences. Plant Cell Environ. 23: 853-862. 
Hernandez, J.A., Ferrer, M.A., Jimenez, A., Barcelo, A.R. and Sevilla, F. (2001) Antioxidant systems and $\mathrm{O}_{2}^{--} / \mathrm{H}_{2} \mathrm{O}_{2}$ production in the apoplast of pea leaves, Its relation with salt-induced necrotic lesions in minor viens. Plant physiol. 127: 817-831.

Hernandez, J.A. and Almansa, M.S. (2002) Short term effects of salt stress on antioxidant systems and leaf water relations of pea leaves. Physiologia Plantarum. 115:251-257.

Hewitt, E.G. (1966) Sand And Water Culture Methods Used in The Study of Plant Nutrition. Technical Communication No. 22, $2^{\text {nd }}$ Edition. Commonwealth Agricultural Bureaux, Fornham Royal, England.

Jebara, S., Jebara, M., Limam, F. and Aouani, E. (2005) Changes in ascorbate peroxidase, catralase, guaiacol peroxidase and superoxide dismutase activities in common bean (Phaseolus vulgaris) nodules under salt stress. J. Plant Physiol. 162: 929-936.

Kant, A.C. and Turan, M. (2011) Hydrogel substance alleviates salt stress with increase antioxidant enzymes activity of bean (Phaseolus vulgaris L.) under salanity stress. Afr. J. Agric. Res. 6: 715-724.

Marschner, H. (1990) Mineral Nutrition of Higher Plants. Academic Press, New York.

Mckersie, B.D. and Leshem, Y.Y. (1994) Stress and Stress Coping in Cultivated Plants. Kluwer Acad. Pub., Dordrecht.

Meneguzzo, S., Navari-Izzo F. and Izzo, R. (1999) Antioxidative responses of shoots and roots of wheat to increasing $\mathrm{NaCl}$ concentrations. J. Plant Physiol. 155: 274-280.

Mittler, R. (2002) Oxidative stress, antioxidants and stress tolerance. Trend. Plant Sci. 7: 405-410.

Mittova, V., Guy, M., Tal, M. and Volokita, M. (2002) Response of the cultivated tomato and its wild salt-tolerance relative to Lycopersicon pennellii to salt-dependent oxidative stress: increased activity of antioxidant enzymes in root plastids. Free Radic. Res. 36: 195-202.

Munns R. (2002) Comparative physiology of salt and water stress. Plant Cell Environ. 25: 239-250.

Nakano, Y. and Asada, K. (1981) Hydrogen peroxide is scavenged by ascorbate specific peroxidases in spinach chloroplasts. Plant Cell Phsiol. 22: 867-880.

Plewa, M.J., Smith, S.R. and Wagner, E.D. (1991) Diethyldithiocarbamate suppresses the plant activation of aromatic amines into mutagens by inhibiting tobacco cell peroxidase. Mutat. Res. 247: 57-64.

Radford, P.J. (1967) Growth analysis formula their use and abuse. Crop Sci. 7: $171-175$.

Rios Gonzalez, K., Erdi, L. and Lips, S.H. (2002) The activity of antioxidant enzymes in maize and sunflower seedling as affected by salinity and different nitrogen sources. Plant Sci. 162: 923-930.

SAS Inst. (1985) SAS User's Guide, Statistics, Version $5^{\mathrm{Ed}}$. SAS Inst. Inc. Cary, Nc.

Tejera, N.A., Campos R., Sanjuan J. and Lluch C. (2004) Nitrogenase and antioxidant enzyme activities in Phaseoulus vulgaris nodules formed by Rhizobium tropici isogenic strains with varying tolerance to salt stress. J. Plant physiol. 161: 329- 338. 
Tejera Garcia, N.A., Iribarne, C., Palma, F. and Lluch, C. (2007) Inhibition of the catalase activity from Phaseolus vulgaris and Medicago sativa by sodium chloride. Plant physiol. Biochem. 45: 535-541.

Tester, M. and Davenport, R. (2003) $\mathrm{Na}^{+}$tolerance and transport in higher plants. Annals Botany 91: 503-527.

Urbanek, H., Kuzniak-Gebarovska, E. and Herka, K. (1991) Elicitation of defence responses in bean leaves by Botrytis cinerea polygalacturonase. Acta. Physiol. Plant. 13: 43-50.

Wang, X. and Han, J. (2009) Changes of proline content, activity and active isoforms of antioxidative enzymes in two alfalfa cultivars under salt stress. Agric. Sci. China. 8: 431-440.

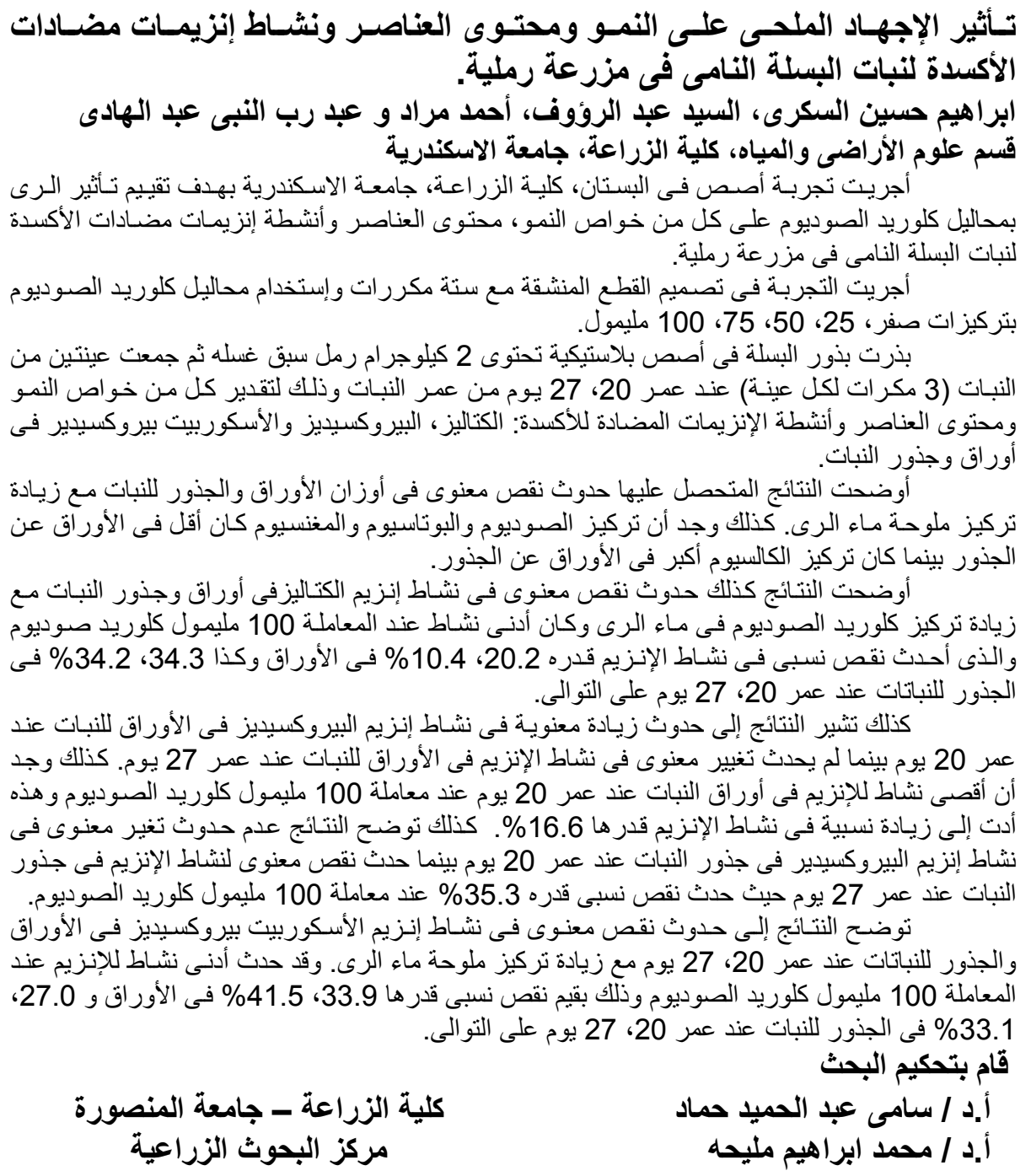

كلية الزراعة - جامعة المنصورة

مركز البحوث الزراعية 


\section{Elsokkary, l. H. et al.}

